JEAN-PHILIPPE RIGAUD

Institut de Préhistoire, Université de Bordeaux 1, FRANCE; j.ph.rigaud@wanadoo.fr

\title{
OBITUARY
}

L ewis Roberts Binford left us on April 11, 2011. With his departure, we lost one of the most creative and influential and, no doubt, controversial archaeologists of his generation. His influence on nature, objects, and prehistoric archaeological theory were quite stimulating, sometimes disturbing, but certainly transformational for the scientific community over the past 50 years. For a good number of us, if not all of us, and each for different reasons, we are in his debt.

Born November 21, 1931 in Norfolk, he was trained (in 1948) in land management and forestry and, following his military interlude that sensitized him to anthropology, he went to on receive his B.A. in 1957 from the University of North Carolina, his M.A a year later, and a Ph.D. from the University of Michigan (Ann Arbor) in 1964. Mentored and nurtured largely by J.B. Griffin and L.A. White at Michigan, his scientific persona was further shaped and influenced individually by his colleagues A.C. Spaulding, E. Odum, J. Steward, F. Plog, S. (Schanfield) Binford, G. Willey, P. Phillips, J.N. Hill, J. Sackett, J. Sabloff, S. LeBlanc, K. Flannery, W.A. Longacre, R. Whallon, and S. Struever.

Many of Binford's students and colleagues have retraced his scientific course better than I possibly could ${ }^{1}$. For my part, I will focus on what I witnessed during Lew and Sally's visits to Bordeaux and the Dordogne region of France between 1965 and 1969, on the amicable confrontation embued with mutual respect with François Bordes, what I took away from my participation in Lew's fieldwork at Anaktuvuk Pass (Figure 1), and our collaboration in 1984 at Grotte Vaufrey.

Twenty-one books and more than 160 publications trace the evolution of his ideas and theoretic underpinnings and, when taken together, present an exceptional body of work through its over-arching importance and its influence on the prehistoric archaeology of the late 20th and the beginning of the 21st century.

It was in 1960, while he was at Ann Arbor, that Binford originated what would later be called the "New Archaeology." This novel way of viewing archaeology as anthropology recognized that, in order to explain all aspects of human societies, it was no longer adequate to merely describe and classify. In opposition to how archaeology had traditionally been practiced as a classificatory and descriptive endeavor, where the data did not allow for new satisfactory interpretations of prehistoric human behavior to be generated,

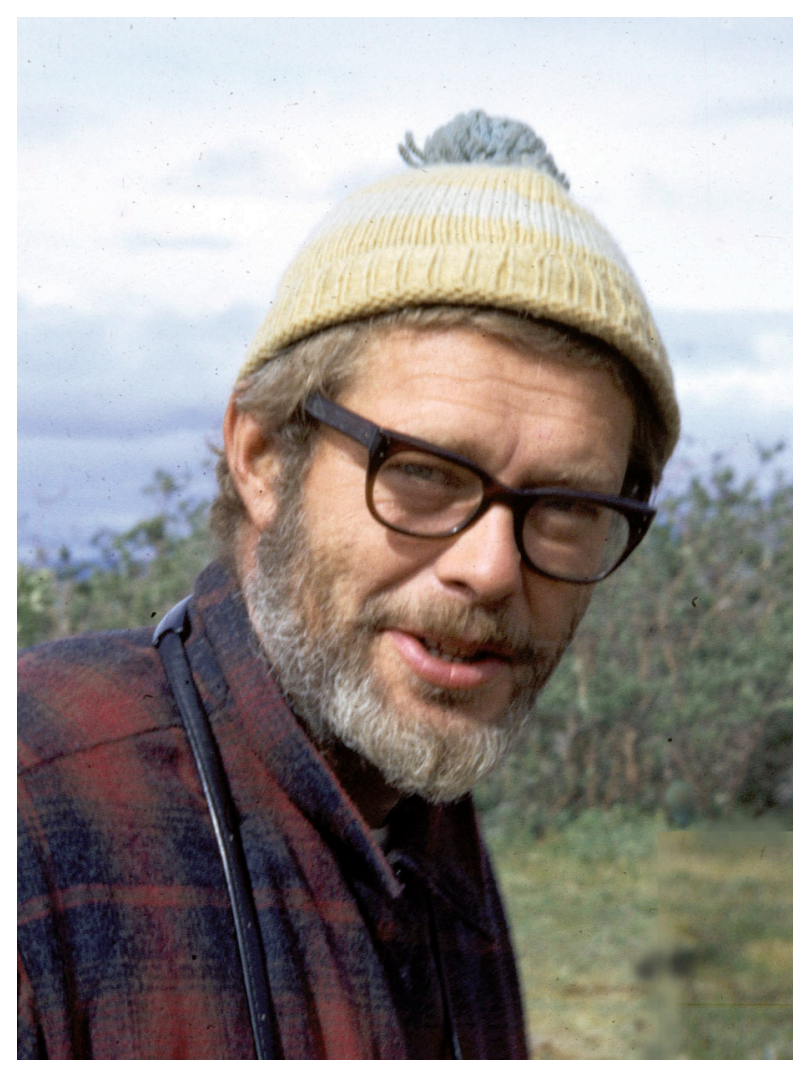

Figure 1. Lewis R. Binford at Anaktuvuk Pass in 1971.

Binford denounced the strictly static character of these data that did not allow for inferences to be made from them. For Binford, it was just the opposite [past behavior was for him, by definition, fundamentally dynamic in nature]; we must first understand the dynamics of recent living hunter-gatherer societies and study the generative processes by which they created the inanimate (static) objects that become the archaeological remnants in order to be able to interpret them in terms of human behavior. This processual archaeology involves the study of recent or past cultural systems, the recognition of multiple fields of investigation, and their reciprocal interactions: technologies, subsistence strategies, procurement and the acquisition of raw materials, mobility, the social structure of human groups, etc. To infer past behavior from archaeological data is accomplished within the context of "middle range theory." According to Binford, it is only through the practice of ethnoarchaeology 
that an anthropological frame of reference for archaeological research can be established.

The ability to evaluate and explain the variability in Mousterian stone tool industries became a seductive idea for Lew and Sally Binford who saw in it a way of testing their approach and method; they made contact with François Bordes who gave them access to the collections from his excavations at Combe-Grenal and Pech de L'Aze.

The participation of Americans in prehistoric research was not new in France. Since the beginning of the 20th century, a succession of archaeologists followed, one after the other, principally in the Périgord-H.-M. Ami, H.H. Kidder, M. Hardy, H. Kelley, G.G. Mac Curdy, H.V.V. Noone, H.L. Movius ${ }^{2}$, but their research in terms of their goals and methods were little changed from that of their French colleagues, which essentially consisted of analyzing, describing, classifying, and interpreting their data in terms of human geography and culture history following the "cultural" guiding principle of the technical tradition.

Prehistoric archaeology during the first half of the 20th century, with all of its habits and customs, was driven by an intellectual approach that ended up by feeding a more and more detailed, varied, and comprehensive corpus of archaeological data, but one that only offered up few understandings of past behavior. Like F. Bordes ${ }^{3}$, his colleagues tried above all to decode, using a technological and typological analysis approach, either the similarities that they believed were inherent in and culturally significant based on a shared stone tool tradition, or the revealing differences based on a relative cultural independence, often based on geographic origins. Thus, Mousterian of Acheulean tradition (MAT) backed knives characterized a stone tool tradition of backed knives or points that continued into the Chatelperronian (Chatelperronian point), then in the Gravettian (Gravettian point) period. Considering the paradigm that they established linking a human type and a 'culture,' this technical continuity held important anthropological implications. F. Bordes, considering that the human type associated both with the Chatelperronian and the Mousterian of Acheulean tradition was (then) unknown, ascribed artisan status to Homo sapiens (Cro Magnon) for the Gravettian industries, as well as for the production of the Chatelperronian and of the Mousterian of Acheulean Tradition (Bordes 1972).

\section{THE BORDES/BINFORD CONTROVERSY}

Diametrically opposed to F. Bordes' cultural explanation, Binford's unambiguous functional explanation (Binford and Binford, 1966) presaged an interesting confrontation when they encountered each other in Bordeaux in 1966. At the time, Lew and Sally Binford's publications were little known to their French colleagues; processual archaeology, the hypothetico-deductive method, the use of statistics (factor analysis), and computers, all gave rise to a wary suspicion that was sustained by some of their detractors as the Binfords' reputation as the Bonnie and Clyde of American archaeology preceded their arrival in France. The critical commentaries leveled revealed more of a lack of knowledge of their work, that up until that point had only been published in English, rather than any actual theoretical or methodological disagreement with the ideas they advanced. Further, the social and political context of this turbulent period was no stranger to these kinds of marked emotions leading to subjective reactions.

At the time, I was a doctoral student at the Institut de Préhistoire (Prehistoric Institute) at the University of Bordeaux directed by François Bordes and the prospect of being a witness to a scientific debate of this importance between these two assertive personalities was especially thrilling. Charged by Bordes with the responsibility to help the Binfords in the laboratory and in the field, I was fortunate to be able to get to know them better and a fast (and complicit) friendship rapidly developed between us. To be a student of Bordes and, at the same time, to subscribe to Binfordian propositions put me in a delicate situation with respect to the witness I had become in this friendly, but sometimes titanic controversy.

The work undertaken by Lewis and Sally Binford in 1966 on the material from the site of Combe-Grenal was at the origin of the animated clash with F. Bordes when the time came to propose an explanation of variability. Given that, each approached the concept from opposite ends of archaeological reasoning, a common meeting point was difficult to find. In fact, the controversy was less a debate than a progressive escalation of arguments of opponents. F. Bordes' deeply held convictions founded on a his own vision of what prehistoric daily life was like and on anecdotal ethnoarchaeological records, were in conflict with Binford's ethnographic models developed from actualistic investigations conducted within various environmental contexts.

For the Binfords, the evaluation of the variability within Mousterian industries was based on quantitative variations of the types of tools and technologically significant objects identified by F. Bordes, but it was more of an accounting than a possible explanation. With the exception of sourcing the lithic raw materials which permitted the reconstruction of a territorial strategy of acquisition, the decoding of the past technical behaviors that led up to stone tool manufacture, took little from ethnographic analogy and much from experimental archaeology and the (subjective?) interpretation of the flintknapper in terms of the possible/probable intentions of the makers. On the other hand, the data coming from the analysis of the faunal remains associated with the lithic industry that had been regarded up to that point solely as temporal and climatic markers, were for $\mathrm{L}$. Binford the behavioral evidence that held a considerable importance for the study of acquisition and consumption strategies, mobility, and seasonality but, in order to do that, an ethnological frame of reference had to be established. And that is just what he undertook in 1969 by initiating research among the Nunamiut Eskimos.

\section{ANAKTUVUK PASS}

It was hoped that the year spent analyzing and plotting the data from Combe-Grenal would establish spatial correlations in the horizontal distribution of lithic artifacts and 
the faunal remains that might shed light on the functional association between technical and food processing activities. The study of the stone tools did not (then) yield much information on the technical activities but, quite the opposite relative to the archeozoological study of contemporary faunal remains that allowed the objective documentation of the exploitation of animal resources.

One settled Nunamiut community at Anaktuvuk Pass at the drainage divide of the Brooks Range who made their living essentially by caribou hunting was chosen for this study that included the excavation, the mapping of different types of settlements, and the analysis of collected material (static data) and the recording of information provided by the Eskimos' behavioral dynamics. Through these missions, the recording of carcass processing, the spatial analysis of food processing, territorial occupation, and mobility were carried out and their publication in multiple works and many articles serve as a unique reference that has nourished and will continue to nourish additional research. My participation in this research was, for me, an exceptional experience that allowed me to study food processing of the Gravettian occupants (26,000 years B.P.) from the site of Flageolet (Dordogne) (Delpech and Rigaud 1974).

The feedback anticipated from this work was, nevertheless, disappointing for the work undertaken at Combe-Grenal where the spatial recording of faunal remains, collected selectively and only by level, was not sufficiently precise to be usable. Lew later recognized his disappointment with the potential that he had overestimated the value of Bordes' data because they were shown to be insufficient to fully attain his goals.

Finally, one positive outcome of this unfulfilled debate seems to have been the diffusion on both sides of the Atlantic and to the core of the international scientific community, of concepts, methods, and theories of European and American schools that differed according to their academic context of origin (naturalist versus cultural anthropology), by their methods, and their goals. Through the Bordes/Binford debate, the impact that the cultural anthropology as "Anglo-Saxon" would have on French Paleolithic archaeology and its actors, strongly attached to the naturalist tradition beyond the Bordeaux and Paris schools, was important, enriching, and stimulating. Poorly known, understood, and interpreted, the ideas supported by Lew Binford were, at the outset, the object of acerbic criticism and often biased, but with time and the development of various international collaborations, his proposals were, little by little, accepted and assimilated (Binford 1980) and, as a result, in 2006 he received the Fyssen Foundation's International Award in Paris.

In 1984, following work and research undertaken in Australia, Kenya, South Africa, and Botswana, Binford returned to France to study the fauna from one Mousterian occupation (Layer VIII) at Grotte Vaufrey (Dordogne) dating to between 200,000 and 250,000 years ago (OIS7). His results led him to think that hominids were not the only ones to inhabit the rockshelter and that predators, as it happened, the dhole (canid), contributed to the accumula- tion of the bone remains, mainly stag and Thar (a type of goat) that could then be exploited secondarily by humans through scavenging. This study called into question the interpretation elaborated at other different Mousterian sites, and even older sites like the Lazaret cave (Lumley [de] 1969).

In 1994, in their re-examination of this faunal study, Grayson and Delpech (1994) reached different conclusions showing, contrary to Binford, that the occupants of Layer VIII at Grotte Vaufrey were far from being inept hunters. For this reason, it is also worth citing the collaborations between J. Enloe and F. Audouze, and M. Julien on the interpretation of Magdelenian open-air sites of Verberie and Pincevent (Audouze 2006; Julien 2003) and the study of J. Enloe on the meat game sharing at the site of Flageolet (Enloe 1994).

That Binford had a tendency to over-interpret the results of his analyses is a reality that one could consider as a blemish of his good qualities. The enthusiasm and the dynamism that he showed across the breadth of his career must have prompted him to too quickly interpret his results and to not devote enough time to consider an alternate possible explanation. We must, nevertheless, recognize that in spite of these few weaknesses, the assessment is a highly positive one and that he opened new avenues that profoundly and forever altered our concept and practice of archaeology.

Those who worked side-by-side with him can testify to his exceptional teaching ability and his persuasive force that some have compared with southern Baptist preachers. Aware of his need to spread the good word, he invested considerable time, energy, and patience in order to persuade people.

That he called into question traditional archaeological practices, and was sometimes excessive in his phrasing, drew aggressive criticism from those who never considered modifying their habits and who wished to quietly keep accumulating their data in the secret hope of making THE discovery that would bring them fame.

On a personal note, I will always remember the several coal miner songs that he magnificently accompanied on the banjo, never-ending friendly conversations as we gazed up at the midnight sun at Tulugak Lake, and, above all, a warm, attentive, and generous colleague.

Jean-Philippe Rigaud

20 January 2012

\section{ACKNOWLEDGEMENTS}

Thanks to Leslie Eisenberg for the translation and to Amber Johnson and Martha Binford for information and help.

\section{ENDNOTES}

${ }^{1}$ Bob Kelly in Science; Mary Stiner and Steve Kuhn in Evolutionary Anthropology; Jim O'Connell in Mitteilungen der Gesellschaft für Urgeschichte, Tübingen; Larry Strauss, Luis A. Borrero, Rosalind Hunter-Anderson, William Longacre, David Meltzer, Dwight Read, Jeremy Sabloff, and Fred Wendorf in Journal of Anthropological Research; David Meltzer in Proceedings of the National Academy of Sciences USA; and most 
certainly others with whom I am not familiar.

${ }^{2}$ And even others who will forgive me, I hope, for not citing them here.

${ }^{3}$ Himself, an intellectual descendant of H. Breuil and D. Peyrony.

\section{REFERENCES}

Audouze, F. 2006. Essai de modélisation du cycle annuel de nomadisation des Magdaléniens du Bassin parisien. Bulletin de la Société préhistorique française, 103: 683-694.

Binford, L.R. 1980. Le rôle de l'ethnoarchéologie dans la recherche archéologique. Nouvelles de l'Archéologie, 3, 4, 31-33.

Binford, L.R. 1988. Etude taphonomique des restes fauniques de la grotte Vaufrey, couche VIII. In La Grotte Vaufrey, Paléoenvironnement, chronologie, activités humaines, J.-Ph. Rigaud (ed.), Mémoire de la Société préhistorique française, t. 19, 1988: 535-563.

Binford, L.R. and Binford S. R. 1966. A preliminary analysis of functional variability in the Mousterian of Lavallois facies. American Anthropologist, 68, 2, 238-295.

Bordes, F. 1972. Du Paléolithique moyen au Paléolithique supérieur, Continuité ou discontinuité ? In Origin of Homo sapiens, F. Bordes (ed.), UNESCO, Paris 1969, pp. 211-218.
Delpech, F. and Rigaud, J.-Ph. 1974. Etude de la fragmentation et de la répartition des restes osseux dans un niveau d'habitat paléolithique. In Premier colloque international sur l'industrie de l'os dans la préhistoire, abbaye de Sénanque, avril 1974. Aix-en-Provence, 1974, l'Université de Provence (ed.), pp. 47-55.

Enloe, J. G. 1994. Le problème du partage du gibier et l'organisation sociale des chasseurs préhistoriques. Annales de la fondation Fyssen, 9: 9-20

Grayson, D.K. and Delpech F. 1994. The Middle Palaeolithic scavenging from couche VIII, Grotte Vaufrey (Dordogne, France). Journal of Archaeological Science 21: 359-375.

Julien, M. 2003. A Magdalenian base camp at Pincevent (France). In Perceived Landscapes and Built Environments: the Cultural Geography of late Palaeolithic Eurasia. XIVe Congrès of UISPP, Liège, 2-8 september 2001, S.A. Vasil'ev, O. Soffer, and J. Kozlowski (eds.). British Archaeological Reports International Series 1122. Oxford, Archaeopress, pp. 105-111.

Lumley (de) H. 1969. Une cabane acheuléenne dans la grotte du Lazaret (Nice). Mémoire de la Société Préhistorique Française 7. 